\title{
An Evil to be Extinguished or a Resource to be harnessed-Informal Sector in Developing Countries: A Case of Zimbabwe
}

\author{
Favourate Y Sebele-Mpofu \& Nomazulu Moyo \\ National University of Science and Technology, Zimbabwe \\ favourate.sebele@nust.ac.zw, nomazulumoyo64@gmail.com
}

\begin{abstract}
The informal sector remains a permanent feature of all economies. It is a more pronounced component of developing country economies where it is an integral part. Literature on economic development offers diverging viewpoints on the sector's contribution to economic growth. On the one hand, researchers view the sector with positivity as a resource to be harnessed, capable of growth and innovation and on the other hand with negativity as a pure survivalist strategy and a stumbling block to effective policy formulation and economic development. Therefore as an inconvenience to be extinguished. The ambivalent view is further compounded by the sector's paltry contribution to national tax revenues and as such, the IS has remained unappreciated and largely on the peripheral of economic reviews and policy responsiveness. The former view suggests that the latter is a misconception and narrow recognition of the sector as merely survivalist and contributing negligibly to employment creation and poverty alleviation efforts. Failure to recognize a coexistence of both street traders and firms with potential for growth, improved productivity and innovation, has consequently resulted in misguided policies. Policymakers pay little or no attention to the potential of informal sector firms, the challenges they face, the vulnerability they are exposed to and the appropriate support they require. This gap motivates this paper, as it seeks to explore the role played by the IS in developing countries with a special focus on Zimbabwe. The study employs a mixed-method research design. The research established that the sector remains unequivocally a major source of employment for many developing countries. It also established that a single-minded focus on formalizing the sector, linked to registration for tax purposes, ignores the other arm to the equation that is the creation of job opportunities, hospitable working conditions, improved productivity and increased profits which are possible with adequate policy support. The research recommends improved policy research and support which is development focused to aid informal firms to grow and be independent institutionally and financially from their owners as well as skills capacitation to improve operational and financial management.
\end{abstract}

Keywords: Informal sector, innovation, poverty alleviation, employment, policy.

\section{Introduction}

The informal sector (hereafter IS), is viewed as an integral component of developing countries' economies. It is said to be occupying a pivotal role in African economies, representing a substantial piece of cake of the gross domestic product, pegged at 50 to $80 \%$ (GDP), a weighty share of economic activity estimated at more than $50 \%$, a considerable slice of employment at around $70-90 \%$ and an extensive composition of firms (Bhorat, Naidoo, \& Ewinyu, 2017). Despite its predominance, "systematic studies of the IS in Africa are few and some important dimensions are not well understood" (Benjamin \& Mbaye, 2012). Literature on informality offers diverse views on the informal economy's impact on economic development. Some scholars proclaim that it promotes the development and economic growth ((La Porta \& Shleifer, 2014; Udoh), is a major resource for developing nations (Tanzanian Revenue Authority, 2010) and the biggest source of employment in African economies (Benjamin \& Mbaye, 2020), yet others attest to the contrary.

The researchers argue that the sector has negative implications (Mpapale, 2014; Kristoffersen, 2011; Maconachie \& Conteh, 2021). The general opinion according to Banik (2011) is that the existence of an informal economy hampers the development of countries. Enquobahrie (2004) however, avows that the informal sector should be recognized as a significant socio-economic force that should be reckoned with, in the development process, particularly in poverty alleviation efforts and job creation in developing countries. In affirmation, Average (2020) describes the sector as "a seedbed for economic development". Cichello and Rogan (2016) affirm the prevalence of the "controversial" view of the IS as a second economy depicted by poverty and lack of development, including being structurally detached from the formal one. They allude to the failure to recognize the importance of the sector in South Africa (SA) as a source of employment, sustenance for livelihoods and poverty reduction. The researchers point to the role of the IS being under- 
recognized and not only in SA but in other developing nations as well and Sub-Saharan Africa (SSA) in particular.

This under-recognition has led to policy gaps and misguided policies towards the IS as policy responses often overlook this sector or are sometimes hostile (Cichello \& Rogan, 2016; Rogan, 2019). Pimhidzai and Fox (2011) allude to the fact that SSA countries hold a negative view towards the informal sector, often to the detriment of policy prescription. Policymakers are generally neglecting the sector's irrefutable contribution to economic development, poverty reduction and people's survival as well as household incomes. Fourie (2018) concurs on this concern, asserting that the IS has remained unappreciated and largely on the peripheral of economic reviews and policy consciousness. Blaauw (2017) notes that the unrecognized, main feature of the informal economy is that, it can play a vital role in unlocking entrepreneurial potential which could otherwise be trapped and suffocated in a net of formality. Despite the notable positive contribution of the informal economy, other researchers maintain that the IS has far-reaching negative consequences on economic development. Most of the activities associated with the informal economy generate insufficient income for the participant to support the family.

Some researchers argue that the sector's expansion impedes the quality of work, goods and services in society and creates unfair trade competition against the formal sector. The sector results in loss of taxes due to non-payment of taxes by the IS, increased non-compliance by the formal sector in response to the ballooning IS and hinders the availability of statistics for policy formulation, (Mpapale, 2014; Kristoffersen, 2011). As proclaimed by Mazhar and Meon (2017), the inability to tax the informal economy "erodes the tax base" and reduces tax revenues collected, thus compromising the government's power to finance public expenditure. Schneider (2002) affirms that the sector is an extortionate constricting of the tax base and a likely misrepresentation of economic activity. The informal sector commonly exceeds $40 \%$ of GDP in developing countries and Zimbabwe has the second-largest IS in the world estimated at $60.6 \%$ of GDP (Medina \& Schneider, 2018). These statistics signify that a greater proportion of output goes untaxed as it continues to be unrecorded or undeclared. Such erosion of the tax base consequentially impacts negatively on government finances. The paradox is, therefore, how to exploit, promote and harness the positive elements in a way that attempts to mitigate the undesirable consequences of the IS.

Earnings also tend to drop as participants move closer to subsistence level activities (Viljoen, 2014). The implications of IS growth for economic policy have continued to be a fundamental concern for policymakers, attracting considerable theoretical interest and recurring in debates in recent years, with disparate perspectives (Emran and Stiglitz, 2005; Jackson, 2012; Kamete, 2020). The varying viewpoints could be linked to developed and developing country platforms where perceptions towards the IS differ as observed by Munjeyi (2017) citing Gurtoo (n.d). Developing countries perceive the IS as a discreditable phenomenon to be eradicated yet developed countries view it as an asset to be drawn on, supported and harnessed for economic development (World Bank, 2011). Jackson (2012) adduces that the informal sector is important in the skills development and provision of employment in emerging economies, yet it remains understudied at household, individual and firm-level. The ambivalent policies and attitudes towards the IS in developing countries are not enabling the crafting of appropriate policies and strategies (Moyo \& Gumbo, 2021; Pimhidzai \& Fox, 2011; Potts, 2008) towards " employment, employability and skills development as well as longer-term stainable human development" in the sector (Jackson, 2012:2902).

Unraveling this puzzle places paramount weight on the need to explicate the impact of informality on the economy and contextualize it to developing country and continent contexts as well as individual national settings. In recognition of the perpetual growth, prevalence and the permanent nature of the IS phenomenon, researchers and policymakers are implored to take a closer look at the value, importance and contribution of this sector to economies especially in a developing country context like Zimbabwe. Failure to acknowledge the contribution of the IS to socio-economic growth, revenue mobilization and in other areas would result in misdirected and misguided macro-economic policies. Khavul, Bruton, and Wood (2009:1220) state that economic informal activities remain pivotal to all economies in the world and more so in African economies where they are a predominant feature, but the activities remain largely unexamined. Accordingly, Oviedo (2009) proposes that policy packages need to be adapted to the nature of informality in a country. In some countries, regulatory reform might be more appropriate, while in others enforcement and administrative or 
tax reform might be in order, hence the need to contextualize the problem in developing country context such as Zimbabwe.

This paper explores the role of the IS in developing country contexts and the Zimbabwean economy particularly. The second section of this paper reviews the literature on the growth, drivers and implications of the IS. It outlines the nature, size and growth of the informal sector in developing countries and in Zimbabwe, to show the magnitude of this sector. The section also briefly explores the drivers of informality in developing countries as well as the role and importance of this sector, to evaluate the emergence and growth of this sector against its implications for policymakers. Section 2.3 discusses the contribution of the informal sector to livelihoods, employment creation and economic development in developing countries and Zimbabwe in particular, which is often a subject of controversy amongst researchers and policymakers. Section 3 describes the methodology used for data gathering while section 4 discusses the findings of the study. The last section concludes and proposes possible recommendations.

\section{Literature Review}

Informal Sector in Developing Countries (Nature and Magnitude): There is no consensus on the definition, meaning, nature, magnitude, composition and roles of the IS among researchers, despite numerous researches on the IS (Dube \& Casale, 2016). Various definitions have been given to this sector and these have had policy implications too. For example, others define the sector as an informal economy, the shadow economy, the underground economy, the hidden economy, the cash economy and the second economy among other names (Becker, 2004; Joshi, Prichard, \& Heady, 2013). Some researchers define the sector as one whose statistical data is not obtainable easily and with economic activities and incomes neither registered nor captured in the tax net, yet others argue that only defining the sector in relation to registration and tax payments is a narrow definition of it (Joshi \& Ayee, 2008; Meagher, 2018; Pimhidzai \& Fox, 2011). Tatariyanto (2014) argues that the IS exists mainly to evade paying taxes from incomes emanating from both legitimate and illegal activities and deliberately do not comply with regulations. Becker (2004) posits that due to its heterogeneity the sector can be categorized by way of two definitions. Firstly, by economic activity (as the sector made up of producers of goods and services with the main aim of generating employment and subsistence incomes for those participating. These activities are small-scale and with little capital. Lastly, by income and employment enhancing likelihood.

This definition includes enterprises that are operating in the IS and can potentially be substantial contributors to national income, economic growth and wealth generation. This class includes individuals who operate in the sector for survival reasons due to low barriers to entry, low capital requirements as well as those that are formally employed but due to low and irregular salaries, they operate informally to supplement the consequence of these controversies and contradictions has been the need for a more contextualized understanding and research that recognizes the informal sector can be burgeoning and growing rapidly in some countries and declining in some (Becker, 2004). The resultant effect is varying policy prescriptions. The IS in Zimbabwe has been growing rapidly in view of declining formal activities and has become the largest employer. The Zimbabwe Economic Policy Analysis and Research Unit and Bank Association of Zimbabwe (Zeparu \& Baz, 2014) state that like many other countries in Africa, Zimbabwe's IS comprises of predominantly trade-related activities that account for 51.9\%, whilst manufacturing and construction accounts for $16.7 \%$ and the remaining percentage being other services. The informal sector has been used to describe activities that escape the tax net, regulation as well as official measurement. Zimbabwe's IS activities include hairdressing, tailoring, wood and stone carving, welding.

Carpentry and other activities that require less capital and marginal input such as construction, farming and manufacturing (Dube \& Sanderson, 2014; Njaya, 2015). According to the ILO (1972:41), IS activities are neither taxed nor monitored by regulators. Researchers have agreed on the characteristics of the IS activities to include low capital and labor, small scale operation, labor-intensive, low technology, easy entry, high level of competition, limited capacity for accumulation, unreported and unrecorded revenues and unregulated activities (Dube, 2014; Jackson, 2012). These activities include activities carried out by Micro, Small and Medium Enterprises. Dalu, Maposa, Dalu, and Pabwaungana (2013) suggest that Zimbabwe's IS could be among the largest in Africa contributing 40 to $50 \%$ to GDP and with an estimated \$7 billion circulating in this 
sector between 2010 and 2014. When studying more than 158 economies around the world, Medina and Schneider (2018) conclude that Zimbabwe and Bolivia have the largest informal economies contributing $60.6 \%$ and $62.3 \%$ of GDP respectively. Referring to a Finscope Micro, Small and Medium Enterprises (MSME) Survey (2012) which established that there were 3.5 million MSMEs with an estimated turnover of US\$7.4 billion or $63.5 \%$ of GDP and employed 5.7 million people in Zimbabwe, Ndiweni and Verhoeven (2013) affirm that the level of informality in Zimbabwe is undisputedly high.

Drivers of Informality and their Theoretical Framework in Developing Countries: Researchers point out the need to theorize the drivers of informality as an underpinning for effective designing of policies towards addressing the informal sector. For example, Wedderburn, Chiang, and Rhodd (2012) state that, "it is essential to first understand the size of the informal economy and the sources of its growth to develop a rational, enforceable tax system". Equally the consequences of informality on the economy can be traced back to the motivations for operating in the IS. A number of theories have been propounded to try and anatomize the emergence and growth of the informal economy (Chen, 2012; Wilson, 2011). Most scholars theorize four broad approaches to studying the source, dynamics and persistence of the informal economy and these are: the dualist approach by Lewis (1954) and Hart (1973), the structuralist approach (neo-Marxist perspective), the legalist (neoliberalist school of thought) by De Soto (1989) and the continuum approach by Maloney (2004). It will be quite inadequate to explore the implications of the emergence and growth of the IS for developing economies (its role, evaluate whether it's a resource or an inconvenience to economies) and Zimbabwe in particular, without fully comprehending what drives informality. Several reasons for the emergence and growth of the IS have been tabled by researchers and these have been accordingly linked to the IS development theories. Jackson (2012) contends that the IS growth is driven by: limited capacity of the formal sector to absorb surplus labor.

The barriers to entering or operating in the formal sector (such as high costs, stringent government regulations, taxes and corruption), redundancies due to the effects of structural adjustments programs that took place around the early 1990s and globalization. The researcher also includes the lack of commitment and willingness of developing countries' governments to address the IS as well as the economic challenges and hardships. Schneider and Williams (2013) attribute the growth of the IS in developing countries to the rootless nature of the businesses in the sector, onerous tax and social security burden, the complexity of tax systems, formalization costs, the prevailing social and economic conditions, quality of government institutions and government spending. Gerxhani (2004) attributes the emergence and growth of the sector to low tax morale, weaknesses in tax collection and the low probability of detection due to fragile tax administration capacity in developing countries. Despite the varying submissions on what drives the IS in developing countries, the different researchers' arguments seem to revolve around unfavorable economic conditions, poverty, the high tax rates and social security burdens, weak tax administration, government spending that is neither responsible, transparent nor accountable as well as high costs of formalizing and other regulatory burdens. It is important to point out that these reasons sometimes do not perfectly fit in IS growth theories, some might be overlapping in the various theoretical perspectives or do not fit at all in any of the theories. The general theorizations as crystallized theories pointed out earlier are briefly expounded on below.

The Dualist Perspective: In the dualist approach the informal economy is viewed as independent from the modern industrialist sector; marginal and subsistence-oriented, offering a safety net to low-skilled (poor) rural to urban migrants seeking to earn a living in any way they can (Hart, 1973) (ILO, 1972). As posited by Lewis (1954), the informal sector was theorized as a phenomenon that is expected to slowly shrink, fade and eventually become invisible due to the development and modernization of the economy. According to Onwe (2013), this school of thought considers the existence of the IS as a signal for underdevelopment. This viewpoint of the informal economy as just a passive homogeneous entity, overlooking the peculiarities and dynamics within it is an oversight and misguided conceptualization that has contributed to inappropriate analyses and incorrect policy planning and implementation. Wilson (2011) argues that in practice, the dualist description is misleading as evidence shows an array of firm types from the most informal to the wholly formal and, businesses often moving along this continuum, some striving for formalization, with others falling into informality. 
Reiterating this concern the African Union (AU) (2008) pose the question, whether the IS should be viewed as "a marginalized 'survival' sector that mops up excess labor or the retrenched workers or a part of a vibrant and growing entrepreneurial component of the economy which has the potential to stimulate economic growth and job creation. In acknowledgment, Onwe (2013) avers that the perception that activities in the IS are merely survival and not worthy of being a subject for consideration under the economic policy should be replaced with the recognition that the sector includes both survivalist activities as well as dynamic, growing and stable enterprises (a continuum referred to by Maloney (2004). This view was also raised by Potts (2008) who points out that "conceptualization of the informal sector in terms of economic dualism has a long history as having effective challenges to those conceptualizations". The researcher further warns that the sector neither is backward nor peripheral to the formal sector but rather an essential part of it and arguing for completely extinguishing or formalizing it is rather misconceived. Concomitantly, the policy approach should focus on support, empowerment and enable the sector. Economic policy should adequately and earnestly take cognizance of the needs and constraints of those in the sector (Fourie, 2018).

The Structuralist Perspective: The structuralist approach stresses the linkages between the formal and informal economies and emphasizes that the latter is included and exploited by the former. It focuses on the informal economy as a product of privileged capitalists attempting to reduce the costs of production by hiring informal labor and subordinating small and micro businesses (Blaauw, 2017). Contrary to the structuralist view that considers the IS subordinate to the formal one, Onwe (2013) adduces that the IS does not exist independent of the formal economy but instead it is closely connected to the formal economy as the sector produces goods and services, trades with and distributes for the formal economy. The IS aids in risk management, the supply of inputs and cost reduction ways to the formal sector hence an important element of the modern economy. Therefore the sector indirectly contributes significantly to economic growth, despite arguments that it does not contribute to economic growth.

The Legalist Perspective: The legalist approach views the informal economy as a reasonable response to overregulation in the formal economy. The argument is that informal operators as rational actors weigh the costs and benefits of operating in the IS and chose to operate informally and the costs of operating formal such as burdensome and onerous regulation such as license fees, registration and taxes including paying pensions, development levies and other social security burdens(Becker, 2004; Chen, 2012). Wilson (2011) described it as a view of the informal economy as a breeding ground for emerging entrepreneurs, constrained only by discouraging and unnecessary legislation to venture into the formal sector. The micro-entrepreneurs opt-out of the overregulation of business by the government by going informal.

Continuum: Pimhidzai and Fox (2011) allude to the fact that the different theorizations that explain informality (legalist, structuralist and dualist) are not entirely divergent. They argue that there may be a coexistence of the tax evaders, the genuinely marginal and subsistence and those that have been sub-contracted by the formal sector. It is apparent from the literature that in some countries the IS has small and erratic incomes (Hart, 1973; Pimhidzai \& Fox, 2011) while in some countries the large informal firms are big enough to be formal exist (Benjamin \& Mbaye, 2012). The coexistence points to informality being a continuum that cuts across several dimensions and theories. A number of researchers documented this continuum (Benjamin \& Mbaye, 2014; Gajigo \& Hallward-Driemeier, 2012; Perry et al., 2007). In view of the co-existence perhaps a once size fit all kind of policy prescription would not be ideal. Policymakers should consider how to support and grow the small firms and accordingly make efforts to bring the large informal firms that are formal in all dimensions but evade tax.

The Role Played by the IS in Developing Countries. A resource or Inconvenience?: Contrary to the economic situation in developed countries where the formal sector is the backbone of the economy, in developing countries especially African countries the formal sector plays a limited role and is confined to cities and towns (Dlamini \& Schutte, 2020). In these developing countries, the majority of the population is rural-based hence they depend solely on the IS (Haan, 2006; Fox \& Gaal, 2008). The informal sector contributes $30-40 \%$ of total rural income as advanced by Steel and Snodgrass (2008) and provides the youth in developing countries with employment (Fox, Senbet, \& Simbanegavi, 2016). There is no unanimous view or consensus on the role, impact or contribution of the IS to the economy of developing countries (Onwe, 2013; Machemedze et al., 2018). Others hold the perspective that it promotes illegal and fraudulent activities that 
rob economies of the much-needed tax revenues, encourages unfair competition, results in a loss of regulatory control and infringes on government legitimacy. The IS threatens the security of economies (especially with shadow activities such as dealing in drugs and human trafficking) and violates the health and safety standards of nations (Bongwa, 2009).

On a different perspective, others hold the IS as a consequential source of employment creation, an accessible market and a provider of goods and services for low-income earners at affordable prices. In affirmation, the Bank of Industry points out that sustainable and inclusive economic development, as well as employment creation, cannot afford to overlook the potential, peculiar requirements and constraints of the IS. The debate on the IS rages on with others considering an under-utilized source of employment that must be enabled (Cichello \& Rogan, 2016; Fourie, 2015, 2018), yet other scholars consider it an inferior source of employment (Potts, 2008). Hassan (2018) asserts that discussions about the role of the IS in the economy and the need to formalize it often ignore the development policy and social interests of the weaker power base of those in the IS. It is imperative to adequately comprehend the dynamics of the sector and how to maximize its potential and mitigate the possible negative impacts of the sector. Cassim, Lilenstein, Oosthuizen, and Steenkamp (2016) assert that informality might promote inclusive growth or may constrain inclusive growth depending on the nature of informality as well government support given to the sector.

Muzenda (2016), while investigating whether the IS can be used as an engine for sustainable development, in Zimbabwe, states that the renewed interest in studying the IS, its impact and contribution to the economy and society in developing countries is key in policy design and implementation. This is because the sector constitutes a very significant part of the countries' macroeconomic environment. In the same line of thought ZEPARU and BAZ (2014) contend that the Zimbabwean economy has gone through a structural transformation in the past decade that saw the IS occupying a prominent position in the economy. This transformation implies that traditional businesses models and economic policies need to be revamped to adopt new mechanisms that are best able to recognize the importance of the IS in economic growth and development, job creation, GDP, taxation and poverty alleviation. Controversies and contradictions have emerged especially on the sector's potential contribution towards development, poverty reduction, employment creation and above all tax revenue (IMF, 2012:12). Therefore in light of this, discussion on these key elements that form the born of contention in debates on the impact of the IS are discussed individually below to lay a foundation for empirical research.

Contribution to Employment Creation: The role of the IS in employment creation is debatable among researchers. Fourie and Kerr (2017) describe the IS as a source of livelihood, subsistence income and employment for millions of people in developing economies, yet Debrah (2007) though acknowledging this role, considers informal employment as an unemployment window dressed as employment. This is because working conditions are generally unfavorable in this sector. Chen (2012) approximates informal employment in Sub Saharan Africa (SSA hereafter) at 72\% excluding the agricultural sector. Adom and Williams (2014) observe that in Ghana the main source of employment is the IS. In Uganda, Fox and Pimhidzai (2011), as well as Pimhidzai and Fox (2011), argue that the IS should be appreciated as an important source of livelihood, accounting for an increasing share of employment and output in SSA and Uganda. The case is similar in Zimbabwe to the other African countries mentioned, as without doubt arguably the IS plays a crucial role in employment creation. It is the largest employer in the country (Dube \& Sanderson, 2014; Dube, 2014; Muzenda, 2016; Njaya, 2015). The IS acts as a safety net for the thousands of retrenched Zimbabweans both skilled and unskilled. This is evidenced by the burgeoning IS during ESAP, the land reform program.

The Indigenisation and Economic Empowerment Act and ultimately in times of economic meltdown in Zimbabwe (Coltart, 2008). This was because the formal business had been highly crippled during this time due to poor economic growth rates, inadequate capital and shortage of foreign direct investment. In Zimbabwe, almost $90 \%$ of the population is informally employed. The informal sector absorbs vulnerable groups such as women in most African countries (Benjamin \& Mbaye, 2014; Ligomeka, 2019). ZIMSTAT (2015) found that 2.8 million small businesses created 5.7 million jobs and medium-sized businesses created 2.9 million jobs. Rahin (2015) avows that the IS contributes favorably to employment generation, poverty eradication and provision of a seedbed from which future taxpayers can join the formal sector. Despite the sector playing such a tremendous role in employment creation, there has been no consensus amongst 
researchers about the role of the IS in stimulating broader economic development through that employment (Debrah, 2007; Ndiweni \& Verhoeven, 2013; Kamete, 2020). Others relegate the IS to low productivity employment, survivalist strategies with little contribution to economic development (Ebeke \& Ehrhart, 2012; Hart, 1973) Debrah, 2007 and others upgrade it to a true contributor to unemployment reduction and creation (Fourie, 2018; Pimhidzai \& Fox, 2011). The ILO (2013) submits that the large portion of the world's workforce that is operating in the IS are often engaged in indecent work.

Low-quality jobs, poverty, low productivity and are confronted with exclusion and discrimination as well as insecurity and vulnerability in the labor market. Re-affirming the unfavorable perception on jobs generated in the IS, Theodore et al. (2015) argue the IS enterprises do not uphold legal and fiscal regulatory requirements such as quality standards, health and safety expectations, intellectual property and copyrights as well as fiscal obligations. In Zimbabwe researchers on informality agree on two important facts and these are: (1) the IS employment is characterized by indecent work at times, unsafe and precarious work, lack of regulation and social security, irregular incomes which are low and lack of legal and regulatory protections for both workers and owners. (2) The recognition that despite the vulnerability of the sector, it indeed employs the majority of the Zimbabwean populace and requires due recognition by the government as such policymakers need to view it with a non-antagonistic lens (Dube \& Sanderson, 2014; Dube, 2014; Mbiriri, 2010; Muzenda, 2016). Jobs in Zimbabwe's formal sector have been exhibiting negative economic growth whereas those in the IS have shown positive economic growth. Government and policymakers need to accept the meaningful contribution that this sector makes to employment creation and help nurture the sector to help it contribute more.

To economic growth and development as well as to tax revenue mobilization. Mbiriri (2010), brings out yet another interesting angle on the IS and employment literature that despite the IS having a low resource base, being labor-intensive and using adapted technology, with experience over time, the enterprises and individuals in the sector are likely to expand, employ and train more people. Adom and Williams (2014) further buttress this point by alluding to the fact that the IS contributes greatly in the training of the labor force in the acquisition of artisanal skills (traditional apprenticeship system), laying an indigenous base as a foundation for industrialization. Haan (2006) contends that about half of the IS workers in Kenya, Senegal, Tanzania, Zambia and Zimbabwe have either no education or primary education and at times only 5\% have tertiary education. Therefore most of these people do not meet entry requirements into colleges and universities hence it is nearly impossible to get formal training creating a skills gap that is filled by the IS. Sometimes also formal training in colleges is said to be too theoretical focused, lacking sufficient practice opportunities, too rigid and standardized to meet the multi-skilling needs of the business environment and such shortcomings are addressed by the IS (Haan,2006; Fox and Gaal, 2008; World Bank, 2008).

The traditional apprentice is undoubtedly a great component of skills transfer and development in Zimbabwe. This is also affirmed by Magidi and Mahiya (2021) who avow that the IS contributes through vocational training, soft skills development (bargaining or negotiation and conflict resolution) as well as entrepreneurial skills development such as marketing, budgeting, costing and sales and customer care. The IS also increases the pace of innovation, as in some cases small innovative companies are purchased by large companies who take advantage and invest in the innovations, produce and market the products. There is no doubt that the IS in developing countries, in Africa, SSA and Zimbabwe in particular contributes immensely to production, consumption and employment creation as well as income generation. In addition, it is a source of survival and a safety net for the poor and the unskilled in countries where formal jobs are scarce or formal sector growth is stagnant. Haan (2006) studying the contribution of the IS to employment creation in SSA provides evidence in Kenya, Zimbabwe and Tanzania that a large number of the youths acquire skills in the IS under the guidance of the master. In Kenya $40-60 \%$ of youths acquire their skills through traditional apprenticeship.

Erosion of the Tax Base: The presence of a huge informal sector in developing countries and African countries particularly, has been linked to the erosion of the tax base (Kundt, 2017; Rogan, 2019; SebeleMpofu \& Mususa). Therefore there is no denying that the IS alleviates poverty and the suffering of many, ultimately contributing to growth and development in developing country context. The avoidance or failure to honor their tax obligations and security payments by the IS has arguably narrowed the tax base of most developing countries, pushing the tax burden to the formal sector, hence disproportionately taxing formal 
enterprises (Joshi, Prichard, \& Heady, 2014; Makochekanwa, 2020; Pfister, 2009). The informal sector is posited to contribute insignificantly to national tax revenues in most developing countries. The sector is said to be driven by tax evasion (Joshi et al., 2014). The Tax Justice Network (TJN), (2011) approximates tax losses due to tax evasion at 5\% of the world's GDP, $40 \%$ of total tax revenues and $6 \%$ of GDP in Africa and $17 \%$ of total tax revenues and 4\% of GDP in Asia. Auriol and Warlters (2005) assert that the tax loss due to informality in developing countries is often exaggerated as some important dimensions are often overlooked, especially the fact that the IS contributes to value-added tax (VAT), through their purchases of inputs, goods and services from the formal sector but unlike the formal sector that claims input tax, the IS enterprises do not.

This view is shared by Fourie (2018) in South Africa and reiterated by Dalu et al. (2013) who portend that the IS contributes to the household incomes of the majority of Zimbabwe, who in turn contribute to VAT through their purchases, hence the sector contributes indirectly to the tax basket. Alm, Martinez-Vazquez, and Schneider (2004) expostulate that the economies characterized by a high level of informality are generally associated with lower tax compliance levels in the formal sector. Pimhidzai and Fox (2011) submit that the view that depicts the IS as tax evaders is rather misguided and ambivalent as the sector pays tax though not to the national government but to local authorities. The sector contributes to government revenues through various payments and levies such as licenses fees and other operating levies. In addition to already contributing to tax, incomes in the IS are generally very low, unstable and for some places seasonal, implying that some of the incomes are below the incomes tax and valued added tax thresholds. This explains that some players might not necessarily evade tax but the level of their incomes and taxable supplies respectively make them exempt from tax. This view was shared by Meagher (2018) in Nigeria and Ligomeka (2019) in Zimbabwe. Sebele-Mpofu (2021) attributes the non-tax compliance in Zimbabwe's IS to the fractured social contract between the state and its citizens.

The failure by the government to be responsive, accountable and transparent in the use of tax revenues diminishes tax morale and trust in the state. Thus fuelling informality and non-tax compliance. Benjamin and Mbaye (2012), though acknowledging the low incomes levels in the IS they point to the presence of large informal firms that are as big as formal firms and have similar operations as these formal firms except that these evade tax. Maloney (2004) and Adams (2008) allude to an influx of the educated, highly skilled and professional such as lawyers, doctors, consultants, engineers and others into the IS due to the potentially high incomes and flexibility of operating in the sector. From the arguments from literature as tabled by different researchers, it is apparent that the IS in some developing countries is a continuum that houses both the lowskilled and highly skilled that operate in the sector because of survivalist needs and by choice respectively. Accordingly, policy prescriptions must recognize the two scenarios and customize policy strategies to the needs and constraints of the sector. Joshi and Ayee (2008) suggest that defining the IS purely based on registration for taxes and formalization ignores important issues.

The focus should not be so much on registration for tax purposes but largely on the constraints to growth and modernization such as limited access to infrastructure and public services such as training and empowerment, in areas such as finance and accounting as well as risk management and marketing. SebeleMpofu and Msipa (2011) submit that developing countries' governments should try to understand the challenges affecting tax compliance in the IS (such as low incomes, low tax morale, inadequate tax knowledge, poor government-stakeholder engagement, high tax rates, complexity and multiplicity of taxes among others) and ameliorate to improve the sector's contribution to tax revenues. Meagher (2018) calls for the restoration of the social contract that is damaged and for the need for stakeholder engagement on policies affecting the growth, operations and revenue contribution of the sector. Similar sentiments are raised by Machemedze et al. (2018) who argues that in Zimbabwe the IS needs are ignored by the government, dialogue and engagement are lacking.

Poverty Alleviation: Pimhidzai and Fox (2011) lament the "ambivalent" attitude displayed by governments in SSA and the body of literature on employment and economic development towards the IS. The researchers argue that the role played by this sector towards economic development and poverty reduction is often disregarded. Providing evidence in Uganda, they show that the sector is an indispensable part of people's livelihoods and a major driver for poverty reduction (Fox \& Pimhidzai, 2011). The negative perceptions 
towards the IS are evident in the actions of some African countries through their efforts to extinguish the sector. For example, in Kenya and Zambia in the 1990s and in Zimbabwe in 2005 through the government operation Murambatsvina (get rid of dirty) that led to demolishing of informal businesses and their structures (Jackson, 2012; Potts, 2008). In Zimbabwe, just like the rest of SSA, poverty is a serious challenge. The Zimbabwean population poverty was compounded by declining living conditions, chronic shortages of goods and cash, hyperinflation as well as high unemployment. According to Mbiriri (2010), a 2003 Poverty Assessment Study Survey showed that $72 \%$ of the population was living below the Total Consumption Poverty Line (TCPL) compared to 55\% in 1995. The relationship between IS growth and poverty reduction is mixed and contradictory (Klapper et al., 2010; Mbiriri, 2010).

While scholars like Pimhidzai and Fox (2011) posit that the IS has become an integral component of the economies in developing countries and SSA by reducing poverty, others argue that the IS traps its actors in poverty. The latter argument is built on the very characteristics of the IS that is low-quality employment, poor working conditions and low wages as well as lack of social protection. Proponents of this view argue that based on these, the IS accentuates poverty contrary to reducing it. They state that working in the IS means poverty. The earnings for small companies operating in the IS are often very low as compared to those of the big formal firms hence the small firms are often referred to as the "working poor" (Haan, 2006). Contrary to the latter view, the former view upholds the significant role played by the IS in poverty reduction. In Zimbabwe, the IS has become strategic as it undeniably enabled the country to survive the worst economic crises in history by providing a source of livelihood to the majority of the population (Mbiriri, 2010; Muzenda, 2016; Ndiweni \& Verhoeven, 2013; Ngundu, 2012). Mbiriri (2010), specifically alludes to the cross-border trade as one key activity of the IS that played a great role in moderating economic hardships, reducing poverty and enhancing human development in the country.

One wonders what the situation in Zimbabwe would have been like in the absence of the IS, with the rate of unemployment of between $80 \%-94 \%$. According to Muzenda (2016), the majority of the population would have lived in abject poverty. Ncube (2013) concurs that the IS can be successfully used as a tool for poverty reduction as well as one to foster economic growth and development. Fox and Gaal (2008) allude to the fact that countries with a significant portion of the households operating in the IS have lower rates of poverty. Mbiriri (2010) explains the role played by the IS in Zimbabwe by arguing that the sector provides a number, of critical and social benefits that accrue simultaneously and buttress the operations of the formal sector. These are summarised as follows: minimization of operating costs through outsourcing from the IS sector by formal firms (leads to employment creation), training (traditional apprenticeship leads to skills transfer and innovation) and economic buffering (safety net for the poor and illiterate hence reducing poverty) (Mbiriri, 2010). It can, therefore, be said to be playing an important role in poverty reduction in Zimbabwe and contributing towards GDP, a contribution which Schneider (2002) approximated at 59.4\%.

Undue Competitive Advantage Over the Formal Sector: Kristoffersen (2011) and Mpapale (2014) contend that the IS benefits from its informal nature through having an unfair competitive advantage over the formal sector. The argument being that goods produced and some services are often similarly differentiated only through branding, packaging and quality. Exploiting their non-payment of taxes, formal operating costs and security burdens, the IS charges relatively lower prices for their products, disadvantaging sales of the formal sector because goods from the two sectors compete for similar resources, markets and customers. This argument has been questioned by researchers such as Bongwa (2009) and Rogan (2019) who argue that the argument overlooks that the formal sector claims the VAT input tax, is eligible for other tax exemptions and deductions not available the IS and also has access to good infrastructure, services such as training, funding and capacitation for tax purposes. All these points to the formal sector have an unfair advantage over the informal sector. The structuralist view suggests linkages and synergies between the formal and the IS. This indicates that some incomes earned in the IS are spent in the formal sector and vice versa (Nakamba-Kabaso \& Phiri, 2012). According to Dube (2014), there are linkages between the IS and the formal sector in Zimbabwe, the IS contributes to the revenue flows of both local and national treasury through supplying inputs to the formal sector. This trade relationship allows the formal sector to increase production and resultantly profits as well as the amount of corporate tax. 
VAT and PAYE among other taxes paid by the corporate world (Mbiriri, 2010; Njaya, 2015). Viewed from the other side of the coin, the IS purchases goods and services from the formal sector thus stimulating demand, increasing production and consumption and ultimately economic activity if not growth. The IS also employs a significant number of people who are supporting the majority of the households in the country, their purchasing activities of various households and significantly contribute to productivity, economic growth and revenue mobilization. During the times of economic distress and liquidity challenges in Zimbabwe, the IS provides a source of raw materials and many other products that the formal sector cannot source due to foreign currency shortages (Mawowa \& Matongo, 2010; Mbiriri, 2010). The IS because of its flexibility is able to access foreign currency from the parallel market. The sector contributes nearly half of global employment and $90 \%$ of new jobs in developing countries. Chibisa (2009) states that the role of the IS in Zimbabwe is often overlooked and underestimated as it lacks official recognition and support, despite this sector having saved the country from complete economic collapse and devastation. Mbiriri (2010), on the same note, adds that between 2000 and 2008, the IS was an instrumental tool in providing the basic needs of millions of Zimbabwe and inputs for a number of companies in the formal sector. This sector is, without doubt, an important part of Zimbabwe's macroeconomic environment, essentially acting as a buffer, a mechanism for poverty alleviation and a platform for employment creation.

Economic Development: The IS that houses most Micro Small and Medium Enterprises is crucial for the development of in African economies, because these enterprises drive growth, generate employment and empowerment opportunities for youth, provide a customer base for formal companies and access to the supply chain to low-income earners. In affirmation (Mbiriri, 2010) postulates that the IS has literally kept the wheels of most developing countries in motion during times of economic downturn especially in Zimbabwe. Enquobahrie (2004) argues that the IS promotes economic development in developing economies, contributing a huge chunk to GDP. In Nigeria the sector was argued to be a major contributor to employment as well as to GDP, contributing approximately 65\% of the GDP in 2017. These jobs help contribute to economic development and growth through income empowerment and poverty alleviation. The sector acts as a springboard for development, providing employment as well as a platform for entrepreneurship, helps distribute resources and provides a source of innovation and competitiveness (La Porta \& Shleifer, 2014; Udoh). Fourie (2018) suggests that the informal sector's contribution has the potential to be even greater. He points out that an empowered, well reinforced, effective and enterprising IS can lead to inclusive growth and contribute sustainably and substantially to economic growth. IS produces various goods and services that are added up to the national output.

Ndiweni and Verhoeven (2013) assert that the IS creates value in Zimbabwe by providing products and services to a market to meet unsatisfied demand and through their ability to creatively respond to challenge and needs. This ensures the IS provides competition and increases product supply, thereby generating economic growth. Saunyama (2013) observes that the flexibility and malleability of the IS traders enable them to be more responsive to clientele needs hence filling the gap that the inflexibility of the formal sector creates in the supply chain. Cassim et al. (2016:12) hold a different view on the contribution of the IS to economic development, submitting that a huge IS "uses and congests public infrastructure without contributing tax revenue to finance it", thus lowering the quality and quantity of these public goods and services. SMEs are regarded as engines of economic growth and vehicles of employment for both developed and developing economies (Chinomona \& Pretorius 2011; Tshuma \& Jari, 2013).

This is further supported by Eniola and Ektebang (2014) who argue that SMEs have a prodigious potential for sustainable development. Chigova (2014) states that the IS has led to increased domestic investment in Zimbabwe in the face of declining foreign direct investments. The increased incomes, as well as economic activities, have seen the IS firms and individuals accumulating savings which have enabled continued investing and reinvesting. As such, the IS contributes significantly to Zimbabwe's GDP. One major social contribution is that the IS keeps the majority of the population occupied and economically empowered hence the reduced crime levels in the country (Chigova, 2014; Mbiriri, 2010). The SMEs also serve as the breeding ground for entrepreneurs and providers of employment in Zimbabwe. Observes that small businesses in Africa have the ability to become large companies in the future that can propel growth and prosperity if only they can be supported appropriately, especially now that they face a gloomy future due to the covid-19 pandemic and lockdown restrictions induced challenges. 
Hampers Supply of Reliable Information and National Statistics: The invisible nature of the IS, the hidden activities, the unavailability of complete, reliable and accurate statistics on the sector casts doubt on some governance and policy decisions(Van der Molen, 2018; Sutcliffe \& Court, 2005. Policymaking and implementation must be guided by evidence and adequate information. Affirming the challenges of the sector's unrecorded, unmeasured and unaccounted for activities, Kristoffersen (2011) asseverates that the IS diminishes the integrity of national statistics and brings forward challenges for tax policy crafting decisions as statistics from the sector are often misleading and unreliable in relation labor, incomes, employment, economic growth, output and potential tax revenues. Enquobahrie (2004) avows that governments are partly responsible for the lack of information on the IS or its inadequacy as some governments paid minimal or attention to the IS and are not committed to gathering the required information or statistics. This could be due to the "ambivalence and invalidation" of the IS described by Kamete (2020) in Zimbabwe or the ambivalent view referred to by Pimhidzai and Fox (2011) in Uganda and Sub Saharan African countries or the negative view of the IS due to non-registration for tax purposes alluded to by Joshi and Ayee (2008) and Meagher (2018) in Ghana and Nigeria respectively.

Challenges Hindering the IS to Contribute Effectively to the Economy: Traditionally, efforts have cantered on the need to regulate informal businesses and formalize them. Little emphasis has been made towards identifying what drives growth in the various subsectors of the IS and how challenges faced by participants can be alleviated (Hassan, 2018; Jackson, 2012; Wedderburn et al., 2012). The IS faced a lot of challenges that cripple its contribution to the economy. Various studies point out that the informal sector is constrained by factors such as inadequate funding and lack of financial support from the government, taxation, poor accounting and risk management, poor infrastructure, lack of training opportunities, low profits as well as ambivalent government policies towards the sector (Bruhn \& Loeprick, 2014; Jackson, 2012; Loeprick, 2009). The covid-19 negative impact has also dampened their survival potential, ability to provide sustainable employment as well as contribution to future economic growth.

Theoretical and Conceptual Framework: This study is guided by the theoretical framework as discussed in Section 2 of this study. The theories that drive the growth of the IS (dualist, structuralist, legalist and continuum), ultimately influence the sector's contribution to the economy. Policymakers must understand these drivers and the challenges faced by the IS and consequently, ensure these are addressed through policy prescriptions to improve the sector's contribution. The way the sector is viewed by the government has an impact on how policy consider it in policy crafting, whether is viewed as a resource to be harnessed or evil to be totally extinguished. The role of the IS in the economy is moderated or impacted upon by the drivers of informality and how the challenges affecting the sector are dealt with in the different national context as suggested by Wedderburn et al. (2012) when studying IS taxation in Jamaica and Jackson (2012) while focusing on the informal economy in Sub Saharan Africa. The sector's contribution to various facets of the economy as derived from the theoretical framework is schematically portrayed in Figure 1.

Figure 1: Conceptual Framework

\begin{tabular}{lll} 
Independent Variable $\quad$ Moderating Variables $\quad$ Dependent Variables \\
\hline
\end{tabular}






\section{Research Methodology}

This study adopted a pragmatic research philosophy, employing a sequential exploratory mixed-method research design (Creswell \& Clark, 2017). This design allowed for the researchers to combine both the qualitative (literature review, conceptual framework design and semi-structured in-depth interviews) and quantitative (use of questionnaires) research approaches under one study. The use of mixed methodologies allows researchers to exploit the advantages of both methods while minimizing the impact of their weaknesses (Creswell, 2013; Guetterman, Fetters, \& Creswell, 2015; Ryan, Coughlan, \& Cronin, 2007). Mixed method research (MMR) is argued to be more suited for researching under-researched areas, vulnerable populations such as low-income earners and the IS and for exploring novel and controversial subjects(Creswell \& Clark, 2017; Creswell \& Tashakkori, 2007; McKerchar, 2008). MMR was considered more appropriate because the IS which is the subject of this research is considered a disadvantaged population that has low incomes and is operating in the IS for survival purposes if the economic dualist approach by Hart (1973) is anything to go by.

The sector is described as under-examined and its role in the economies of developing countries is considered under-evaluated (Cassim et al., 2016; Jackson, 2012). The sector's role as well as economic impact is contestable and surrounded by ambivalence and invalidation (Kamete, 2020; Moyo \& Gumbo, 2021; Pimhidzai \& Fox, 2011). Potts (2008) affirms this unfavorable view, stating that the general policy perception in most developing countries is to get rid of informal activities "through modernization and a shift to higher productivity, more sophisticated technology and more sophisticated technology and more capital". In-depth interviews were conducted with tax consultants, Informal sector association members and officers from the Ministry of SMEs while questionnaires were distributed to IS players to get an insight into the demographics of those that operate in the sector, their reasons for operating in the sector and their perceived contribution to the sector as well as the challenges they face. The qualitative part of the study was conducted first and the results from the qualitative analysis were combined with the concepts extracted from the literature review to develop the questionnaire instrument employed in the quantitative part of the study (Creswell \& Clark, 2017; Fetters, Curry, \& Creswell, 2013).

\section{Discussion of Results}

Demographics of Participants: The interview respondents were all knowledgeable people with educational qualifications higher than an undergraduate degree and vast experiences in their different areas. For example tax, consults had immense knowledge and experience on IS tax administration, advice and filing of tax returns. The IS association members had been members of those associations for more than five years in various capacities and they also owned informal businesses. While the employees in the Ministry of SMEs had more than 5 years of experience, which was good for institutional memory. The IS sector questionnaire respondents were made up of people of various age groups and qualifications as presented in Figure 2. In Table 1 the majority of people (48\%) had an undergraduate degree or more, while $20 \%$ had college Diplomas and the remaining $32 \%$ was made up of $18 \%$ that had up to $\mathrm{A}^{\prime}$ level and $14 \%$ that had no education or up to $0^{\prime}$ level. It was evident that contrary to the views by researchers such as Becker (2004) and Hassan (2018) those players in the sector had a low qualification.

The dualist view by Hart (1973), that depicts operators in this sector as low-skilled and low education, players in Zimbabwe's IS were highly educated and held some formal qualifications. This suggests that the operators are in this sector not because of low education levels and lack of training, but for other reasons. This could perhaps be linked to the influx of professionals and skilled personnel to this sector as suggested by Maloney (2004) and Adams (2008). Table 1 presents the results of the drivers of informality in relation to the age groups of participants as a way of trying to explicate why these skilled professionals are in this sector. As a way of trying to assess the role played by the IS through the age composition of the respondents' operation in the sector, respondents were asked to show their age range. In Figure 2, more than $50 \%$ of those that were operating in the IS were between 36 to 45years of age (52\%), 27\% were aged between 26 to 35 years, $8 \%$ were below 25 years while $13 \%$ were above 45 years. It was clear that most of the people in the IS included the youths and young adults. 
Figure 2: Ages of Informal Sector Questionnaire Respondents

\section{Ages of IS operator questionnaire respondents}

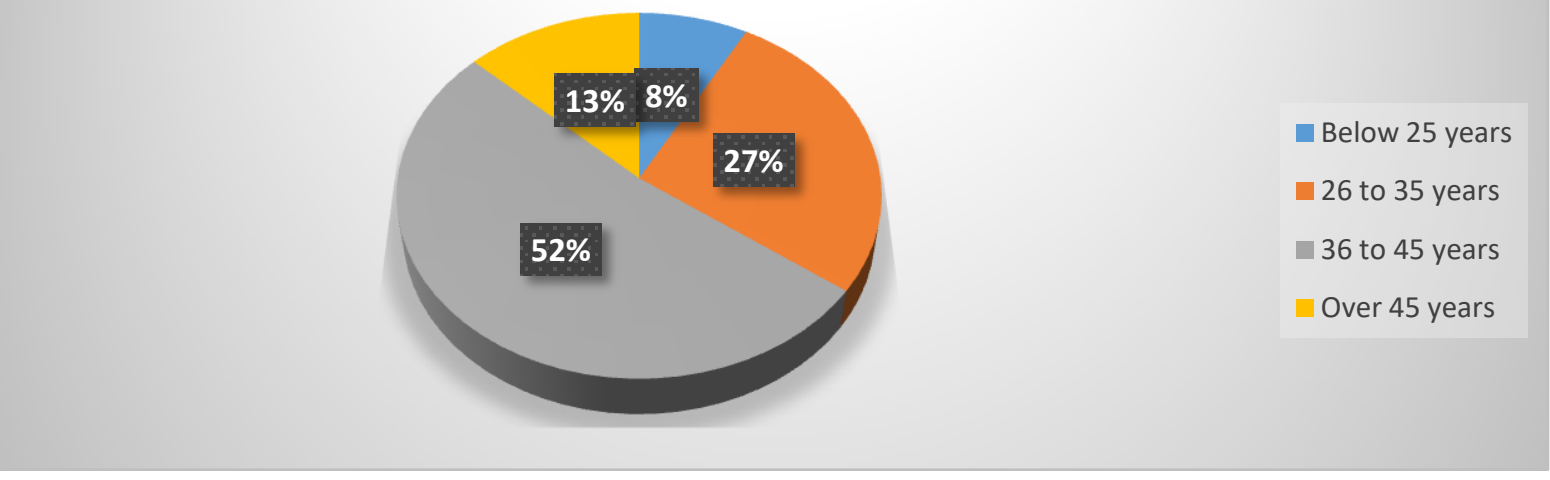

Source: Own Compilation

Drivers of Informality: On the drivers of informality the factors that were largely identified by many interviewees as what drove them into the IS were survival (91\%), unemployment (85\%), retrenchment $(60 \%)$ and ease of entry into the IS (54\%). The other factors such as high incomes (36\%), flexibility (40\%) and lack of education and training (20\%) were not considered as important determinants of informality. It was apparent from the results that most of the operators in the IS in Zimbabwe were not in the sector out of choice but were driven there by the poor economic conditions in the country which have led to retrenchments and high rates of unemployment. These players are in the sector due to the need to earn survival. It is clear also that some are in the sector due to high incomes and flexibility, reflecting a rational choice though they are just a minority. The interviewees for the qualitative part were purposefully sampled, while the questionnaire respondents were randomly selected from the IS stratas. 200 informal sector questionnaire respondents were chosen.

The interview samples ranged between 5-10 interviews per group in line with guidance from Creswell (2014) who advocates for smaller samples of 3-10 for qualitative studies and Malterud, Siersma, and Guassora (2016) who suggests the use of smaller samples if the sample is informationally powerful. Information power considers the strength of the competencies, experience, exposure and knowledge of those sampled (Malterud et al., 2016; Sebele-Mpofu, 2020). The variations in sample sizes (10 informal sector association members, 5 tax consultants and 3 employees for the Ministry of SMEs) were guided by the achievement of the saturation point. The saturation point was considered as the point where no new themes and insights were still emerging from interviews, hence were making further interviewing futile (Fusch \& Ness, 2015; Hennink, Kaiser, \& Marconi, 2017). Qualitative data analysis was done using NVIVO qualitative data analysis software and the themes and codes were deduced from the analysis were used as some of the variables in the IS questionnaire. The questionnaires were analyzed through SPSS. The IS in Zimbabwe reflects a continuum suggested by Maloney (2004) or a mixed bag by Kristoffersen (2011).

With a combination of those that are driven into the sector by unfavorable economic conditions and lack of employment and those that are there voluntarily. Similar views were expressed by the ISM and TAXC who argued that the IS was made up of many different players that were pushed or pulled into the sector for different reasons. TAXC1 asseverated that it was not entirely correct and fair to define informality from the tax evasion angle. The tax consultant argued that "yes there are tax evaders in the sector. I don't dispute but the majority of players make very little incomes to be able to pay tax and besides the fixed presumptive tax rates are burdensome they have no regard for profitability, turnover or expenses of the small enterprises". ISM1 also expressed that most of their members were merely making enough to keep the business going and pay salaries. Operating in the sector was a matter of earning subsistence incomes and that even then it was difficult because government policies were not considerate when it comes to the IS. The results from the questionnaire analysis were presented in Table1. It is evident that survival is the predominant factor (52\%), followed by unemployment (27\%) and recent retrenchment at $14 \%$. 
Table 1: Reasons for Operating in the Informal Sector $N=200$

\begin{tabular}{|c|c|c|c|c|c|c|c|}
\hline $\begin{array}{l}\text { Age } \\
\text { Range } \\
\text { (years) }\end{array}$ & $\begin{array}{l}\text { High } \\
\text { Income }\end{array}$ & Survival & $\begin{array}{l}\text { Recent } \\
\text { Retrenchment }\end{array}$ & Unemployment & Flexibility & $\begin{array}{l}\text { Lack of } \\
\text { Education } \\
\text { and } \\
\text { Training }\end{array}$ & $\begin{array}{l}\text { Ease of } \\
\text { Entry in } \\
\text { the IS }\end{array}$ \\
\hline $\begin{array}{l}\text { Below } \\
25\end{array}$ & & 11 & & 5 & & & \\
\hline $\begin{array}{l}26 \\
35\end{array}$ & 4 & 20 & 10 & 15 & 3 & 2 & \\
\hline $\begin{array}{ll}36 & \text { to } \\
45 & \end{array}$ & 2 & 61 & 14 & 27 & 2 & 3 & 2 \\
\hline Over 45 & 2 & 13 & 3 & 7 & 1 & & \\
\hline
\end{tabular}

Source: Own Compilation

Contribution of the IS to the Economy: The study participants offered different perceptions with regard to the sector's contribution to the economy in Zimbabwe. There was an agreement between interview participants groups (TAXCs, ISMs and MSMEs) that the IS was an indispensable part of people's livelihoods and the economy in developing countries and Zimbabwe in particular. According to ISM3 "our members contribute greatly to almost all sectors of the economy. Most of our members are involved in various activities manufacturing, sourcing of groceries and medication, distribution and transportation. We hold this economy and make it function". The contribution of IS especially the SMEs was further affirmed by MSME2 who pointed out that the sector contributes to the GDP of the economy through various activities and that the government was aware of that and was putting measures in place to support their activities.

TAXC6 was of the view that the sector is contributing to innovation, entrepreneurship, survival, economic development and employment creation but it is not contributing the way it should. TAXC6 further observed that "let's be honest, the government is not enabling this important sector at all. Take, for instance, the introduction of the ZUPCO buses, the needs, concerns and plights of the passenger transport operators that have been providing transport to the whole of Zimbabwe were not considered, despite them having well-established associations. In the current situation with the covid-19 pandemic, the sector is the hardest hit with no supporting measures". There were mixed sentiments among interviewees on the role of the IS, with some TAXCs pointing to the fact that IS activities curtailed the revenue authority's ability to mobilize tax revenues and led to lower tax morale in the formal sector thus eroding the tax base. Results from the questionnaires were also mixed as shown in Table 2.

Figure 3: The Role Played by the IS in the Zimbabwean Economy

\section{The role played by the IS in the economy}

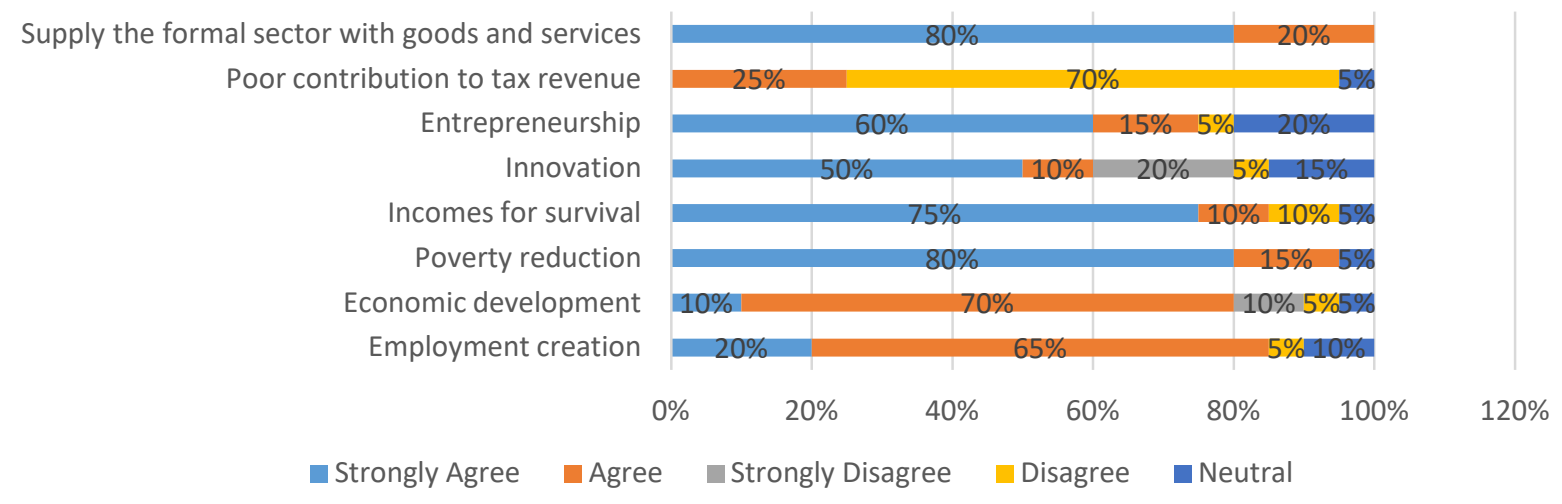

Source: Own Compilation 
Regression Results on the Role Played by the IS: To explore more the role played by the informal sector in the Zimbabwean economy, a regression analysis was done to enhance the qualitative results presented, above and the results of the analysis are discussed below.

Correlation Matrix: We constructed the correlation matrix table for our variables of interest. Variables such as employment creation, poverty alleviation, entrepreneurship development, erosion of the tax base measures were tested to see their correlation effects on economic growth and development in Zimbabwe (measured by GDP per capita). From the results obtained, the measures on the role of informality are strongly correlated to GDP/Capita, with entrepreneurship development at the top, with a coefficient of 0.706 and erosion of the tax base at the bottom, with a coefficient of 0.426. Summary correlation results are given in Table 2 below.

Table 2: Correlation Matrix

\begin{tabular}{lllllll}
\hline & $\begin{array}{c}\text { GDP (light } \\
\text { data) }\end{array}$ & $\begin{array}{l}\text { Employment } \\
\text { Creation }\end{array}$ & $\begin{array}{l}\text { Erosion of the } \\
\text { Tax Base }\end{array}$ & $\begin{array}{l}\text { Poverty } \\
\text { Alleviation }\end{array}$ & $\begin{array}{l}\text { Innova } \\
\text { tion }\end{array}$ & $\begin{array}{l}\text { Entrepreneurship } \\
\text { Development }\end{array}$ \\
\hline $\begin{array}{l}\text { GDP (light data) } \\
\text { Employment }\end{array}$ & 0.583956 & 1 & & & \\
$\begin{array}{l}\text { creation } \\
\begin{array}{l}\text { Erosion of the tax } \\
\text { base }\end{array}\end{array}$ & -0.4263 & -0.1443404 & 1 & & \\
$\begin{array}{l}\text { Poverty alleviation } \\
\text { Innovation }\end{array}$ & 0.623092 & 0.040767566 & 0.964563 & 1 & & \\
$\begin{array}{l}\text { Entrepreneurship } \\
\text { development }\end{array}$ & 0.445431 & 0.201250873 & 0.928632 & 0.97876 & 1 & 1 \\
\hline
\end{tabular}

Note that, even though other relationships presented above are equally important, the correlation between $\mathrm{GDP} /$ capita and other variables is key and central to this study.

OLS Regression: To reinforce our correlation results above, we performed and presented some regression results below.

Table3: Regression Statistics

\begin{tabular}{ll}
\hline Multiple R & 0.774557541 \\
R Square & 0.788450215 \\
Adjusted R Square & 0.76091009 \\
Standard Error & 0.011523662 \\
Observations & 257 \\
\hline
\end{tabular}

The table above shows the explanatory power of our model. Both our R-squared and adjusted values are above $50 \%$, (79\% and $76 \%)$ which clearly shows that our model is powerful. Literally, it means that the selected measures of informal sector role explain the economic growth in Zimbabwe.

Table 4: Regression Coefficients and Statistics

\begin{tabular}{lllllllll}
\hline & $\begin{array}{l}\text { Coefficie } \\
\text { nts }\end{array}$ & $\begin{array}{l}\text { Standard } \\
\text { Error }\end{array}$ & t Stat & P-value & $\begin{array}{l}\text { Lower } \\
\mathbf{9 5 \%}\end{array}$ & $\begin{array}{l}\text { Upper } \\
\mathbf{9 5 \%}\end{array}$ & $\begin{array}{l}\text { Lower } \\
\mathbf{9 5 . 0 \%}\end{array}$ & $\begin{array}{l}\text { Upper } \\
\mathbf{9 5 . 0 \%}\end{array}$ \\
\hline Intercept & 0.0732 & 0.0013 & 0.002 & 0.0020 & 0.0707 & 0.075 & 0.070 & 0.075 \\
Employment creation & 0.8251 & 0.0132 & 0.025 & 0.0322 & -0.0342 & 0.017 & -0.034 & 0.017 \\
Erosion of the tax base & -0.3612 & 0.1447 & 0.026 & 0.0245 & 0.1304 & 1.881 & 0.130 & 1.881 \\
Poverty alleviation & 0.2574 & 0.1643 & 0.026 & 0.0186 & -0.5810 & 0.0663 & -0.581 & 0.066 \\
Innovation & 0.4102 & 0.1527 & 0.216 & 0.0012 & -0.1905 & 0.4109 & -0.190 & 0.410 \\
$\begin{array}{l}\text { Entrepreneurship } \\
\text { development }\end{array}$ & 0.4411 & 0.0804 & 0.054 & 0.0036 & -0.1579 & 0.158 & -0.157 & 0.158 \\
\hline
\end{tabular}


The above results came from the Ordinary least squares regression done in STATA. The coefficients for all the variables are positive which agrees with the correlation results above. Also, the p-values are all less than the level of significance $(5 \%)$ which shows their significance in our model. The final model is given by: $G D P_{\text {capita }}=0.073+0.83 x_{1}-0.36 x_{2}+0.25 x_{3}+0.41 x_{4}+0.44 x_{5}$

Where $X s$ are our variables from employment creation down to entrepreneurship development? All in all, the model results show that an increase in any one of the measures of the role played by the IS, except for the erosion of the tax base results in an increase in GDP/Capita in Zimbabwe. Also, a negative erosion of the tax base (or reduced tax revenue flows from the informal sector is sensible as it is inversely related to economic growth.

Table 5: ANOVA Table

\begin{tabular}{llllll}
\hline & DF & SS & MS & F & Significance F \\
\hline Regression & 5 & 0.0058 & 0.1157 & 88.7122 & 0.2749 \\
Residual & 251 & 0.0333 & 0.0133 & & \\
Total & 256 & 0.0391 & & & \\
\hline
\end{tabular}

To test for linearity, an ANOVA table was constructed. The results suggest that there is linearity among the variables and the response measure (GDP/Capita). This is indicated by a large F value of 88.72 .

Challenges Hindering the IS from Contributing Effectively to the Economy: From the interviews, various challenges were highlighted by participants to constraining the contribution of the IS to the economy. Though interviewees converged on some commonalities on these challenges but they also differed greatly on the importance they attached to some challenges. These variations were nothing out of the ordinary but were considered as reflective of the diversity of participants' views, attitudes and perceptions built from their experiences and their positions as government employees (MSMEs, IS operators ( ISM) and Tax advisors (TAXC). The challenges identified were: lack of adequate financing and financing opportunities, poor management, accounting and risk management practice, the covid-19 pandemic and lockdown restrictions. Lack of government support, low capital, competition, high tax rates and no operating spaces or infrastructure as well as lack of enabling government policies. For TAXCs two reasons were very topical during the discussion and these were the lack of enabling government policies and ARE engagement in policy issues. The tax consultants felt that government policies in relation to the IS including tax policy and tax administration were negative, ill-informed and not supportive of the growth of jobs in the sector or expansion of the IS activities. TAXC6 though acknowledging that developing country governments tend to view the IS with negativity, yet it is a reality of the African continent, gave an example of South Africa's recent measures put in place in response.

To the pandemic that included support to the IS and SMEs as well as leniency in the payment of taxes. This was affirmed by TAXC8 who pointed out that the lockdown restrictions and the costs of protective clothing, sanitizers and masks were heavy costs on small businesses that are unable to recover them as allowable, deductions like their formal business counterparts. For ISMs the prominent factors were taxation, lack of government support and inadequate funding as well as the covid-19 lockdown restrictions. The IS associations members felt that if only their members could be given government support in the form of funding, reduced tax rates and training opportunities and working spaces, their contribution to employment creation, poverty alleviation and economic growth would be better. From the quantitative analysis, the most prominent challenges were lack of capital and funding (95\%). Lack of government support (80\%), taxation (75\%), ambivalent government policies (70\%) and the covid-19 restrictions (60\%). The results from the questionnaires had a resemblance to the discussions with ISMs who highlighted the same sentiments. In relation to the covid-19 induced lockdown restrictions, ISM2 expressed that "our members were highly affected because of the small scale nature of our businesses, we hardly have any reserves or assets to fall back on, yet fixed expenses such as license fees, rates, rent and salaries among other costs need to continue to be honored". These challenges were also affirmed by ISM5 who alluded to cash flow challenges, a reduction in capacity utilization, disruptions in procurements of raw materials, goods and services and no /reduced sales. 


\section{Conclusion, Limitations and Recommendations}

The research concludes that viewing the informal sector from the lenses of an anomaly that should be uprooted is a myopic view and does not represent the IS for what it really is in SSA and specifically in Zimbabwe. The sector contributes consequentially to employment creation and poverty reduction; it is a survival route for a larger portion of the Zimbabwean population. Pushing for the formality of the IS, which is met with serious resistance from the IS, while casting a blind eye to the role by the sector in key areas such as, employment creation, poverty alleviation, innovation and economic development, among others is rather misguided. The study concludes that there is indeed under-recognition of the role played by the sector as policies seem to be unfavorable towards the sector. For example the presumptive tax policy, that does not consider actual incomes and expenses of IS operators. Government-Stakeholder engagements on policy issues tend to overlook the sector. Therefore, there is a need for a more balanced and supportive approach to the IS.

If governments are to derive benefits such as tax revenue generation, Increased, contribution to employment and economic growth. The sector was found to be contributing less than it should to the economy, due to challenges such as lack of adequate financing and financing opportunities, poor management, accounting and risk management practices, lack of government support, low capital, competition, high tax rates and no operating spaces or infrastructure as well as lack of enabling government policies. The research recommends that policymakers should seek to understand the drivers of the growth of the IS, the challenges the sector faces and formulate policies that encourage a positive contribution from the IS. The government is also encouraged to exploit, promote and harness the IS in a manner that brings out its positive aspects while minimizing the negative implications. Further studies could focus more on how policymakers could include the IS in formulating policies that impact favorably on the sector and explore the cost versus the benefits of governments addressing the challenges faced by the IS.

\section{References}

Adams, A. V. (2008). Skills development in the informal sector of sub-Saharan Africa. World Bank.

Alm, J., Martinez-Vazquez, J. \& Schneider, F. (2004). 'Sizing'the Problem of the Hard-to-Tax. Contributions to Economic Analysis, 268, 11-75.

Auriol, E. \& Warlters, M. (2005). Taxation base in developing countries. Journal of Public Economics, 89(4), 625-646.

Average, C. (2020). Contestations for urban space: informality and institutions of disenfranchisement in Zimbabwe-the case of Masvingo City. GeoJournal, 85(5), 1277-1289.

Becker, K. (2004). The informal economy: Fact-finding study: Causes of growth in the informal economy, who participates in it and why: Stockholm: SIDA.

Benjamin, N. C. \& Mbaye, A. A. (2012). The Informal Sector, Productivity, and Enforcement in West Africa: A Firm-level Analysis. Review of Development Economics, 16(4), 664-680.

Benjamin, N. C. \& Mbaye, A. A. (2014). Informality, growth, and development in Africa. WIDER working paper, 52.

Benjamin, N. C. \& Mbaye, A. A. (2020). The Failure of Structural Transformation in Francophone Africa and the Rise of the Informal Sector. Formal and Informal Enterprises in Francophone Africa: Moving Toward a Vibrant Private Sector, 137.

Bhorat, H., Naidoo, K. \& Ewinyu, A. (2017). Increasing Employment Opportunities: Navigating Africa's Complex Job Market. https://www.africaportal.org/publications/increasing-employmentopportunities-navigating-africas-complex-job-market/

Blaauw, P. F. (2017). Informal employment in South Africa: Still missing pieces in the vulnerability puzzle. Southern African Business Review, 21(1), 339-361.

Bongwa, A. (2009). Managing Ethiopian Cities II: Informality in Ethiopia: Taxing the Hard to Tax. No HIS WP 22.

Bruhn, M. \& Loeprick, J. (2014). Small Business Tax Policy, Informality, and Tax Evasion-Evidence from Georgia: The World Bank.

Cassim, A., Lilenstein, K., Oosthuizen, M. \& Steenkamp, F. (2016). Informality and inclusive growth in SubSaharan Africa: Institute of Development https://opendocs.ids.ac.uk/opendocs/handle/20.500.12413/12105 
Chen, M. A. (2012). The informal economy: Definitions, theories and policies. Women in informal economy globalizing and organizing: WIEGO Working Paper, 1.

Chigova, L. E. (2014). An analysis of the fiscal potential of the informal sector on Zimbabwe's revenue base: The case of Glenview home industries. University of Zimbabwe.

Chinomona, R. \& Pretorius, M. (2011). Major dealers' expert power in distribution channels. South African Journal of Economic and Management Sciences, 14(2), 170-187.

Cichello, P. \& Rogan, M. (2016). Informal sector employment and poverty in South Africa: identifying the contribution of 'informal sources of income on aggregate poverty measures. Tackling unemployment and poverty in South Africa: The contribution of the informal sector. Paper for ISEP Book Project. F. Fourie \& C. Skinner (Eds.), Tackling unemployment and poverty in South Africa: The contribution of the informal sector. Pretoria: HSRC Press.

Creswell, J. W. (2013). Research design: Qualitative, quantitative, and mixed methods approach. Sage publications.

Creswell, J. W. (2014). A concise introduction to mixed methods research: Sage Publications.

Creswell, J. W. \& Clark, V. L. P. (2017). Designing and conducting mixed methods research: Sage publications.

Creswell, J. W. \& Tashakkori, A. (2007). Differing perspectives on mixed methods research: Sage Publications Sage CA: Los Angeles, CA.

Dalu, T., Maposa, V. G., Dalu, T. \& Pabwaungana, S. (2013). Awareness and compliance levels of informal traders with regards to their presumptive tax obligations: a case of Harare central business district informal traders. African Journal of Economic and Sustainable Development, 2(4), 297-308.

De Soto, H. (1989). The Other Path: The Invisible Revolution in the Third. World.

Dlamini, B. \& Schutte, D. P. (2020). An overview of the historical development of Small and Medium Enterprises in Zimbabwe. Small Enterprise Research, 1-17.

Dube, G. (2014). Informal sector tax administration in Zimbabwe. Public Administration and Development, $34(1), 48-62$.

Dube, G. \& Casale, D. (2016). The implementation of informal sector taxation: Evidence from selected African countries. eJTR, 14, 601.

Ebeke, C. \& Ehrhart, H. (2012). Tax revenue instability in Sub-saharan Africa: Consequences and remedies. Journal of African Economies, 21(1), 1-27.

Eniola, A. A. \& Ektebang, H. (2014). SME firms performance in Nigeria: Competitive advantage and its impact. International Journal of Research Studies in Management, 3(2), 75-86.

Enquobahrie, A. (2004). Some Controversies on informal sector operation in Ethiopia: Problems and prospects for a development strategy. Paper presented at the PF International Conference on Contemporary Development Issues in Ethiopia, Addis Ababa, Ethiopia.

Fetters, M. D., Curry, L. A. \& Creswell, J. W. (2013). Achieving integration in mixed methods designsprinciples and practices. Health services research, 48(6pt2), 2134-2156.

Fourie, F. (2015). The NDP on unemployment: On consistency, coherence and comprehensiveness: REDI3x3 Working paper 7. Cape Town: SALDRU, University of Cape Town.

Fourie, F. (2018). Creating jobs, reducing poverty: why the informal sector should be taken seriously and enabled properly.

Fourie, F. \& Kerr, A. (2017). Informal sector employment creation in South Africa: What can the SESE enterprise survey tell us? Research Project on Employment, Income Distribution and Inclusive Growth (REDI3X3), University of Cape Town.

Fox, L., Senbet, L. W. \& Simbanegavi, W. (2016). Youth employment in Sub-Saharan Africa: challenges, constraints and opportunities. Journal of African Economies, 25(suppl_1), i3-i15.

Fusch, P. I. \& Ness, L. R. (2015). Are we there yet? Data saturation in qualitative research. The qualitative report, 20(9), 1408.

Gajigo, O. \& Hallward-Driemeier, M. (2012). Why do some Firms abandon Formality for Informality? Evidence from African Countries. African Development Bank, Working Paper Series(164).

Gerxhani, K. (2004). The informal sector in developed and less developed countries: a literature survey. Public Choice, 120(3-4), 267-300.

Guetterman, T. C., Fetters, M. D. \& Creswell, J. W. (2015). Integrating quantitative and qualitative results in health science mixed methods research through joint displays. The Annals of Family Medicine, 13(6), 554-561. 
Hart, K. (1973). Informal income opportunities and urban employment in Ghana. The Journal of Modern African Studies, 11(01), 61-89.

Hassan, B. (2018). Informal Employment Generation and Poverty Reduction in Edo State: The Role of 'Okada'riding. Journal of Arts, Management, Science \& Technology (JAMST), 5(1), 31-44.

Hennink, M. M., Kaiser, B. N. \& Marconi, V. C. (2017). Code saturation versus meaning saturation: how many interviews are enough? Qualitative health research, 27(4), 591-608.

Jackson, T. (2012). Cross-cultural management and the informal economy in sub-Saharan Africa: implications for organization, employment and skills development. The International Journal of Human Resource Management, 23(14), 2901-2916.

Joshi, A. \& Ayee, J. (2008). Associational taxation: A pathway into the informal sector? Taxation and StateBuilding in Developing Countries, 183-211.

Joshi, A., Prichard, W. \& Heady, C. (2013). Taxing the Informal Economy: Challenges, Possibilities and Remaining Questions. IDS Working Papers, 2013(429), 1-37.

Joshi, A., Prichard, W. \& Heady, C. (2014). Taxing the informal economy: The current state of knowledge and agendas for future research. The Journal of Development Studies, 50(10), 1325-1347.

Kamete, A. Y. (2020). Neither friend nor enemy: Planning, ambivalence and the invalidation of urban informality in Zimbabwe. Urban Studies, 57(5), 927-943.

Khavul, S., Bruton, G. D. \& Wood, E. (2009). Informal family business in Africa. Entrepreneurship theory and practice, 33(6), 1219-1238.

Kristoffersen, S. (2011). Taxation and informal sector growth in developing countries. http://urn.nb.no/URN:NBN:no-29645

Kundt, T. (2017). Opportunities and challenges for taxing the informal economy and subnational taxation. K4D Emerging Issues Report. Brighton, UK: Institute of Development Studies

La Porta, R. \& Shleifer, A. (2014). Informality and development. Journal of Economic Perspectives, 28(3), 109126.

Lewis, W. A. (1954). Economic development with unlimited supplies of labor. The manchester school, 22(2), 139-191.

Ligomeka, W. (2019). Expensive to be a Female Trader: The Reality of Taxation of Flea Market Traders in Zimbabwe. https://www.africaportal.org/publications/expensive-be-female-trader-reality-taxationflea-market-traders-zimbabwe/

Loeprick, J. (2009). Small business taxation: Reform to encourage formality and firm growth (Investment climate in practice: Business taxation No. 1). Washington, DC: World Bank.

Machemedze, R., Wadzanai, S., Zhou, J. \& Chirisa, I. (2018). Informal Economy and Social Vulnerability in Zimbabwe, Research Report. Friedrich-Ebert-Stiftung, Zimbabwe

Maconachie, R. \& Conteh, F. (2021). Artisanal mining policy reforms, informality and challenges to the Sustainable Development Goals in Sierra Leone. Environmental Science \& Policy, 116, 38-46.

Magidi, M. \& Mahiya, I. T. (2021). Rethinking training: the role of the IS in skills acquisition and development. Development Southern Africa, DOI: 10.1080/0376835.2020.17999759.

Makochekanwa, A. (2020). Informal Economy in SSA: Characteristics, size and tax potential. MPRA Paper 98644.

Maloney, W. F. (2004). Informality revisited. World Development, 32(7), 1159-1178.

Malterud, K., Siersma, V. D. \& Guassora, A. D. (2016). Sample size in qualitative interview studies: guided by information power. Qualitative health research, 26(13), 1753-1760.

Mazhar, U. \& Méon, P. G. (2017). Taxing the unobservable: The impact of the shadow economy on inflation and taxation. World Development, 90, 89-103.

Mawowa, S. \& Matongo, A. (2010). Inside Zimbabwe's roadside currency trade: the World Bank of Bulawayo. Journal of Southern African Studies, 36(2), 319-337.

Mbiriri, R. P. (2010). Can Zimbabwe use its informal economy as a means for sustainable development in the current reconstruction process? University of the Witwatersrand.

McKerchar, M. A. (2008). Philosophical paradigms, inquiry strategies and knowledge claims: applying the principles of research design and conduct to taxation. eJTR, 6, 5 .

Meagher, K. (2018). Taxing times: Taxation, divided societies and the informal economy in Northern Nigeria. The Journal of Development Studies, 54(1), 1-17.

Medina, L. \& Schneider, F. (2018). Shadow economies around the world: what did we learn over the last 20 years? IMF Working Paper No 18/17 
Moyo, I. \& Gumbo, T. (2021). Modernity, Urban Planning and Informality Urban Informality in South Africa and Zimbabwe (pp. 29-38): Springer.

Mpapale, C. (2014). Broadening the Tax Base in Kenya: The Case of Informal Sector. The East Africa Tax and Governance Network (EATGN), 1-22.

Njaya, T. (2015). Informal Sector, Panacea to the High Unemployment in Zimbabwe? Case of Informal Sector Enterprises of Harare Metropolitan. International Journal, 97

Onwe, 0. J. (2013). Role of the informal sector in development of the Nigerian economy: Output and employment approach. Journal of Economics and Development Studies, 1(1), 60-74.

Perry, G., Maloney, W., Arias, O., Fajnzylber, P., Mason, A. \& Saavedra, J. (2007). Informality: Exit and Exclusion, World Bank Latin America and Caribbean Studies. World Bank, Washington DC.

Pfister, M. (2009). Taxation for investment and development: An overview of policy challenges in Africa. Paper presented at the A Background paper to the Ministerial Meeting and Expert Roundtable of NEPAD-OECD Africa Investment Initiative.

Pimhidzai, O. \& Fox, L. (2011). Taking from the poor or local economic development: the dilemma of taxation of small informal enterprises in Uganda. World Bank Africa Regional Project on Improving the Productivity and Reducing Risk of Household Enterprises, Washington DC.

Potts, D. (2008). The urban informal sector in sub-Saharan Africa: from bad to good (and back again?). Development Southern Africa, 25(2), 151-167.

Rogan, M. (2019). Tax Justice and the Informal Economy: A Review of the Debates. WIEGO Working Paper No 41.

Ryan, F., Coughlan, M. \& Cronin, P. (2007). Step-by-step guide to critiquing research. Part 2: Qualitative research. British journal of nursing, 16(12), 738-744.

Saunyama, T. C. (2013). The contribution of the informal sector trade to poverty reduction in Rusape, Zimbabwe. Unpublished Thesis. University of Pretoria.

Sebele-Mpofu, F. Y. (2021). The Informal Sector, the "implicit" Social Contract, the Willingness to Pay Taxes and Tax Compliance in Zimbabwe. Accounting, Economics, and Law: A Convivium, 1(ahead-of-print).

Sebele-Mpofu, F. Y. (2020). Saturation controversy in qualitative research: Complexities and underlying assumptions. A literature review. Cogent Social Sciences, 6(1), 1838706.

Sebele-Mpofu, F. Y. \& Msipa, C. (2020). Feasibility of Administering Informal Sector Taxation: Approaches and Hurdles. A Case of the Informal Sector in Bulawayo, Zimbabwe. ISSN No:-2456-2165, 5(2), 193- 208.

Sebele-Mpofu, F. Y. \& Mususa, A. (2019). How Successful is Presumptive Tax in Bringing Informal Operators into the Tax Net in Zimbabwe? A Study of Transport Operators in Bulawayo. ISSN No:-2456-2165, $4(3), 79-88$.

Sutcliffe, S. \& Court, J. (2005). Evidence-based policymaking: what is it. How does it work?

Tanzanian Revenue Authority (TRA) (2010).

Theodore, N., Blaauw, D., Schenck, C., Valenzuela, A., Schoeman, C. \& Meléndez, E. (2015). Day labor, informality and vulnerability in South Africa and the United States. International Journal of Manpower, 36(6), 807-823.

Tshuma, M. C. \& Jari, B. (2013). The informal sector as a source of household income: The case of Alice town in the Eastern Cape Province of South Africa. Journal of African studies and development, 5(8), 250.

Udoh, J. E. Taxing the Informal Economy in Nigeria: Issues, Challenges and Opportunities. International Journal of Business and Social Sciences, 6(10), 160-175.

Van der Molen, P. (2018). Informal economies, state finances and surveyors. Survey review, 50(358), 16-25.

Viljoen, J. M. M. (2014). Economic and Social Aspects of Street Pickers in South Africa. Unpublished doctoral thesis, Department of Economics \& Econometrics, University of Johannesburg, South Africa.

Wedderburn, C., Chiang, P. \& Rhodd, R. (2012). The informal economy in Jamaica: Is it feasible to tax this sector? Journal of International Business and Cultural Studies, 6, 1.

Wilson, T. D. (2011). Introduction: Approaches to the informal economy. Urban Anthropology and Studies of Cultural Systems and World Economic Development, 40(3/4), 205-221. 